\title{
PENGARUH WAKTU REAKSI DAN ADITIF GLISEROL PADA SINTESIS SELULOSA ASETAT SEBAGAI BAHAN DASAR BIOPLASTIK DARI SERAT KAPUK
}

\section{THE EFFECT OF REACTION TIME AND GLYCEROL ADDITIVES IN SYNTHESIS OF CELLULOSA ACETATE AS A BIOPLASTIC RAW MATERIAL FROM KAPOK FIBER}

\author{
Rahmatullah $^{1 *}$, R. Wulandari Putri ${ }^{1}$, A. Muhammad Rainadi ${ }^{1}$, A. Permatasari ${ }^{1}$, M. Yori Pratama ${ }^{1}$ \\ ${ }^{1}$ Jurusan Teknik Kimia, Universitas Sriwijaya, Sumatera Selatan, Indonesia, 30139 \\ *main contributor and corresponding author \\ e-mail: rahmatullah@ft.unsri.ac.id, rizkawulandariputri@unsri.ac.id, adhemuhammad73@gmail.com \\ ayupermatasari172@gmail.com,pratama.yori@gmail.com
}

Diterima: 10 September 2019; Direvisi: 17 Juni 2020; Disetujui: 18 Juni 2020

\begin{abstract}
Abstrak
Serat kapuk meiliki potensi menjadi bahan dasar cellulose acetate karena jumlah komposisi selulosanya yang cukup besar yaitu $35 \%-64 \%$. Penelitian ini bertujuan untuk menganalisa produk bioplastik yang dihasilkan dari serat kapuk dengan tambahan plasticizer berupa gliserol. Tahapan penelitian ini terdiri dari: preparasi bahan baku, ekstraksi, sintesa, purifikasi, dan pencetakan. Parameter yang akan diteliti antara lain waktu reaksi dengan variasi 1 , 2, dan 3 jam; dan pembahan aditif gliserol $20 \%, 25 \%$, dan $30 \%$ dari volume CA. Hasil penelitian ini menunjukkan jumlah rendemen selulosa terbanyak diperoleh pada waktu hidrolisis gugus asetil selama 3 jam dengan rendemen sebesar $138,264 \%$ dengan berat sebesar 6,913 gram. Penambahan gliserol $30 \%$ dari volume CA menghasilkan bioplastik terbaik dengan karakteristik fisik lebih kuat dan tidak mudah rapuh bila dibandingkan dengan bioplastik dengan gliserol $20 \%$ dan $25 \%$.
\end{abstract}

Kata Kunci: Bioplastik, Serat Kapuk, Selulosa Asetat

\begin{abstract}
Kapok fiber has the potential to be used as raw material for making Cellulose Acetate. It has high cellulose content of $35 \%-64 \%$. This study aims to analyze bioplastic products from Kapok fiber with the addition of glicerol. This research followed by steps: preparation, extraction, synthesis, purification, and molding. The variation of this research are reaction time for 1, 2, and 3 hours, and glycerol additive $20 \%, 25 \%$, and $30 \%$ by volume CA. The results of this study showed that the reaction time for 3 hours, resulted in the highest yield of cellulose acetate at $138.264 \%$. The addition $30 \%$ glycerol produces the best physical form of bioplastic which is not brittle when compared to bioplastics with glycerol $20 \%$ and $25 \%$.
\end{abstract}

Keywords: Bioplastic, Kapok Fiber, Cellulose Acetate

\section{PENDAHULUAN}

Jumlah sampah plastik yang tercatat di lautan dunia pada tahun 2018 sebesar 150 juta ton. Jumlah ini diperkirakan akan bertambah menjadi 250 juta ton bila kecenderungan urbanisasi, produksi dan konsumsi terus meningkat. Berdasarkan penelitian yang sama menunjukkan Indonesia berada di posisi kedua dari lima negara yang bertanggung jawab atas 50\% dari semua sampah plastik yang ada di lautan. Kelima negara tersebut semuanya berada di kawasan Asia, yaitu China, Indonesia, Vietnam, Filipina, dan Thailand (Ellen MacArthur Foundation, 2016). Pada tahun 2010, Indonesia mempunyai populasi pesisir sebesar 187,2 juta yang tinggal dalam jarak $50 \mathrm{~km}$ dari tepi pantai dan setiap tahunnya memproduksi 3,22 juta ton sampah yang tak terkelola dengan baik, serta diperkirakan mengakibatkan 
kebocoran 0,48-1,29 juta plastik ton sampah plastik per tahun ke lautan (Jambeck et al., 2015). Sampah laut yang tersebar di Laut Indonesia tersebut jika terus menerus dibiarkan dapat semakin menambah kerusakan ekosistem laut yang ada di dalamnya dan tidak menutup kemungkinan sampah tersebut dapat menyebabkan punahnya suatu spesies di lautan. Dua pemicu pokok yang menyebabkan sampah plastik tersebut berada di lautan adalah sampah yang tidak terpungut dan rendahnya nilai beberapa jenis plastik tertentu (McKinsey, 2015). Sampah plastik yang tidak terpungut tersebut tidak dapat terdegradasi sehingga menumpuk terbawa arus di lautan dunia. Salah satu cara untuk mengurangi pencemaran akibat plastik di lautan ini adalah dengan cara mengganti penggunaan plastik konvensional menjadi bioplastik yang lebih ramah lingkungan.

Terdapat tiga tipe utama bioplastik yang diproduksi secara komersial, yaitu plastik turunan dari sumber fosil tetapi biodegradable, plastik turunan dari polimer yang dikonversi dari biomassa dan biodegradable, dan plastik turunan dari polimer yang dikonversi dari biomassa tetapi tidak biodegradable. Pada penelitian ini bioplastik yang diproduksi merupakan tipe bioplastik yang dikonversi dari biomassa dan biodegradable (Aripin et al., 2017). Beberapa contoh jenis biodegradable dan bio-based bioplastik ditunjukkan di tabel 1. Adapun jenis bioplastik yang dibuat pada penelitian merupakan cellulose based materials yang terbuat dari bahan baku serat kapuk randu (Elnashar, 2012).

\begin{tabular}{|c|c|c|}
\hline Bahan Baku & Perusahaan & $\begin{array}{l}\text { Kapasitas } \\
\text { (ton/tahun) }\end{array}$ \\
\hline $\begin{array}{l}\text { Strach based } \\
\text { materials }\end{array}$ & Novamont & 60000 \\
\hline $\begin{array}{c}\text { Cellulose based } \\
\text { materials }\end{array}$ & Innovia Films & 30000 \\
\hline Polylactides (PLA) & Naturework & 140000 \\
\hline $\begin{array}{c}\text { Polyhydroxyalkanoat } \\
\text { (PHA) }\end{array}$ & Metabolix (ADM) & 50000 \\
\hline
\end{tabular}

Tanaman kapuk randu berasal dari bagian utara Amerika Selatan, Amerika Tengah, Karibia, dan Afrika. Tanaman ini dibudidayakan secara luas di daerah tropis karena tanaman ini membutuhkan keadaan yang curah hujannya tinggi. Kapuk randu (C. pentandra Gaertn.) memiliki ketinggian mencapai 8-30 $\mathrm{m}$ dan memiliki batang pohon utama yang cukup besar hingga mencapai diameter $3 \mathrm{~m}$. Batangnya terdapat duri-duri tempel besar yang berbentuk kerucut. Serat kapuknya berwarna putih kekuningan dan mengkilap. Tanaman ini dapat tumbuh pada berbagai jenis tanah, dari tanah berpasir, tanah liat berdrainase baik, tanah aluvial, sedikit asam sampai netral (Pratiwi, 2014).

Indonesia sendiri merupakan negara penghasil kapuk terbesar di dunia sebesar 58.693 ton atau sebesar $62,69 \%$ dari total produksi dunia pada tahun 2015 (FAOSTAT, 2015) Namun saat ini banyak tanaman kapuk yang diabaikan begitu saja tanpa diperhatikan kelestariannya. Hal ini disebabkan karena nilai ekonomi dari tanaman kapuk dianggap bernilai rendah oleh masyarakat padahal serat kapuk tersebut memiliki kandungan selulosa yang berpotensi untuk dimanfaatkan sebagai bahan baku berbagai industri.

Kapuk randu yang dapat dilihat pada gambar 1 , selain memiliki nilai ekonomis juga memiliki fungsi sebagai material penahan tanah dari banjir, erosi, dan tanaman penghijauan yang dapat dimanfaatkan untuk melestarikan sumber daya alam. Namun dari tahun ketahun jumlah permintaan serat kapuk semakin berkurang yang membuat nilai ekonomisnya pun semakin berkurang sehingga membuat tanaman ini semakin kurang diperhatikan para petani (Pratiwi, 2014). Salah satu faktor yang mengakibatkan permintaan kapuk di Indonesia menurun adalah akibat dari persaingan dengan penggunaan bahan sintetis seperti poliester dan poliuretan yang lebih murah dan lebih nyaman digunakan sebagai bahan pengisi dibandingkan kapuk. 


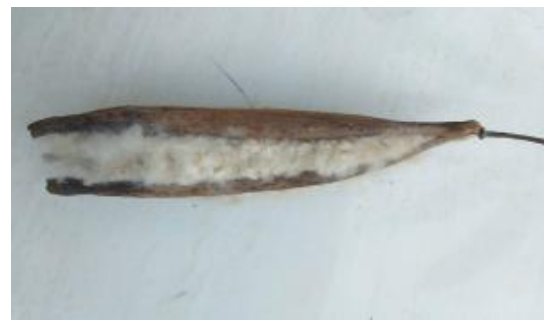

Gambar 1. Kapuk Randu

Masalah lainnnya dari pemanfaatan serat kapuk randu adalah penggunaannya yang masih sangat minim hanya sebagai bahan pengisi kasur, bantal guling atau boneka. Serat kapuk dalam pabrik tekstil tidak diminati untuk dijadikan bahan dasar pembuatan benang. Hal ini disebabkan serat kapuk mempunyai serat yang pendek, licin, rapuh, dan tidak elastis, sehingga sulit untuk dipintal menjadi benang (Raden et al., 2016).

Serat kapuk meiliki potensi menjadi bahan dasar cellulose acetate karena jumlah komposisi selulosanya yang cukup besar yaitu 35\%-64\% (Sugiyanto, 2013).

Beberapa penelitian terdahulu untuk menambah nilai jual dan fungsi dari tanaman kapuk ini sendiri antara lain, kulit batang, batang, dan daunnya dapat dimanfaatkan sebagai obat herbal (Pratiwi, 2014), bungkil bijinya dapat digunakan sebagai campuran briket sekam padi (Asri \& Tjahjani, 2015), serat kapuknya sebagai bahan baku pembuatan kertas (Kathomdani, 2018) dan mikrokristalin selulosa (Raden et al., 2016), minyak dari bijinya dapat dimanfaatkan sebagai bahan baku pembuatan biodiesel (Fajar \& Hendrawati, 2015), serta kulit buahya dapat dimanfaatkan sebagai bahan baku furfural (Andaka, 2016). Berdasarkan studi penelitian terdahulu peneliti belum menemukan adanya penelitian terkait pemanfaatan serat kapuk sebagai bahan dasar dalam konversi bioplastik cellulose acetate.

Selulosa asetat merupakan senyawa ester asam organik turunan selulosa yang memiliki bentuk berupa serbuk berwarna putih (Phisalaphong et al., 2016).
Pembuatan selulosa asetat dapat dilakukan tiga metode antara lain metode solution process (proses larutan), solvent process (proses dengan pelarut), dan heterogenous process (proses heterogen) (Carolina, 2010). Adapun metode yang diambil pada penelitan ini yaitu solution process dengan menjadikan asetat anhidrida sebagai solven, asam asetat glasial sebagai diluen, dan asam sulfat sebagai katalis. Beberapa penelitian terdahulu terkait penggunaan selulosa asetat antara lain sebagai membran (Apriani et al., 2017), biofilm (Syamsu \& Kuryani, 2014), bioplastik (Rohmawati et al., 2018), dan sebagainya. Namun belum ada yang menggunakan serat kapuk randu menjadi bahan baku bioplastik.

Waktu reaksi merupakan salah satu parameter penting terhadap jumlah rendemen selulosa asetat yang dihasilkan, sedangkan penambahan plasticizer mempengaruhi karakteristik fisik dari bioplastik yang terbentuk. Pada penelitian Analda Souhoka \& Latupeirissa (2018), yang membuat selulosa asetat dari $\alpha$ selulosa komersil menunjukkan bahwa pengaruh dari waktu reaksi berbanding lurus terhadap jumlah selulosa asetat yang terbentuk, namun waktu reaksi masih terlampau lama yaitu memakan waktu 5 jam. Untuk pengaruh penambahan plasticizer gliserol terhadap karakterisik fisik bioplastik yang dibentuk telah dilakukan oleh Sjamsiah et al., (2017) dalam pembuatan edible film dari pati kentang, pada penelitian tersebut menunjukkan bahwa semakin banyak penambahan plasticizer maka karakteristik edible film yang terbentuk akan semakin tebal dan kuat.

Berdasarkan beberepa penelitian tersebut maka dilakukan pembuatan selulosa asetat dari serat kapuk sebagai bahan baku bioplastik untuk mengetahui pengaruh waktu reaksi dan persentase gliserol terhadap rendemen selulosa asetat dan karakteristik fisik bioplastik berbasis serat kapuk. 


\section{BAHAN DAN METODE}

\section{Bahan}

Kapuk Randu Taman Pasca Sarjana Unsri Palembang. Bahan kimia: Bleaching Agent (NaOCl 5,25\%), Asam Asetat Glasial $98 \%$, Asam Sulfat 98\%, $\mathrm{NaOH} 17,5 \%$, Asetat Anhidrat 99,5\%, Gliserol 99\%, dan Aquadest (Brataco Chemical).

\section{Metode Penelitian}

\section{Persiapan Bahan Baku}

Penelitian ini merupakan modifikasi dari penelitian Braun, dkk (2013). Serat kapuk dibersihkan dengan bleaching agent komersial kemudian dicuci bersih dan dioven pada suhu $100^{\circ} \mathrm{C}$ hingga berat konstan. Serat kapuk yang telah dibleaching kemudian diekstraksi menggunakan larutan $\mathrm{NaOH} 17,5 \%$ selama 3 jam . Serat kapuk yang telah diekstraksi kemudian dicuci bersih dengan menggunakan aquadest hingga derajat keasamannya $(\mathrm{pH})$ netral dan dikeringkan dengan menggunakan oven hingga berat konstan.

\section{Sintesa}

Sebanyak 5 gram serat kapuk yang telah diekstraksi di dalam labu leher tiga kemudian dimasukkan $50 \mathrm{~mL}$ asam asetat glasial dan asam sulfat $98 \%$ pada suhu ruangan dan dalam keadaan tertutup. Proses asetilasi dilakukan setelahnya dengan menambahkan campuran $50 \mathrm{~mL}$ asetat anhidrat dan $20 \mathrm{~mL}$ asam asetat glasial dan dipanaskan dalam water bath pada $50^{\circ} \mathrm{C}$ sehingga menghasilkan primary Cellulose Acetate (CA). Temperatur water bath dijaga agar tetap konstan. Primary CA ini kemudian ditambahkan asam asetat glasial dan asam sulfat. Reaksi berlangsung dengan variasi waktu reaksi selama 1,2 , dan 3 jam.

\section{Purifikasi}

Larutan hasil sintesa berupa selulosa asetat dimasukkan ke dalam beker gelas 1 $\mathrm{L}$ dan ditambahkan $500 \mathrm{~mL}$ aquadest dengan pengadukan, kemudian didiamkan sehingga selulosa asetat akan berubah menjadi fase padat. Larutan disaring menggunakan corong Buchner dengan penambahan aquadest hingga netral. Selulosa asetat yang telah netral kemudian dikeringkan dengan oven pada suhu $100^{\circ} \mathrm{C}$ hingga berat konstan.

\section{Pembuatan Bioplastik}

Sebanyak 1 gram selulosa asetat ditambahkan gliserol (20\%, 25\%, 30\% dari berat selulosa asetat) dan $1 \mathrm{~mL}$ aseton sambil diaduk di dalam cetakan, kemudian didiamkan pada suhu ruangan hingga selulosa asetat kering.

\section{Pengujian}

Pengujian dilakukan dengan cara menimbang produk selulosa asetat yang dihasilkan dari reaksi selulosa asetat. Kemudian pengujian pembuatan bioplastik dengan menggunakan selulosa asetat tersebut sebagai bahan baku dengan variasi penambahan plasticizer berupa gliserol sebanyak $20 \%$, $25 \%$, dan $30 \%$ dari berat selulosa asetat. Pengujian lain yang dilakukan adalah analisa kualitatif terhadap penampakan bioplastik yang dihasilkan (tekstur dan warna).

Adapun matriks penelitian seperti yang ditunjukkan pada Tabel 2 berikut.

\begin{tabular}{cccc}
\multicolumn{3}{l}{ Tabel 2. Matriks Penelitian } & \\
\hline Sampel & $\begin{array}{c}\mathrm{t} \\
\text { (Jam) }\end{array}$ & $\begin{array}{c}\text { Berat } \\
\text { (gram) }\end{array}$ & Persentase (\%) \\
\hline 1 & 1 & & \\
2 & 2 & & \\
3 & 3 & & \\
\hline
\end{tabular}

\section{HASIL DAN PEMBAHASAN}

\section{Hasil Bleaching dan Ekstraksi Serat Kapuk}

Proses bleaching ini dilakukan untuk menghilangkan atau membersihkan kapuk dari kandungan warna, debu, dan wax yang masih terkandung di dalamnya. Proses bleaching yang terlalu lama dapat merusak rantai hemiselulosa dan selulosa yang terkandung di dalam serat (Astuti, 2005). 
Kapuk yang telah bersih, kemudian diekstraksi menggunakan $17,5 \% \mathrm{NaOH}$ untuk mengambil kandungan selulosanya. Pemilihan larutan ini dikarenakan pada larutan $17,5 \% \mathrm{NaOH}$ kandungan lignin, hemiselulosa, selulosa beta dan gamma yang ada didalam serat kapuk akan terlarut didalamnya dan menyisakan selulosa alfa dengan derajat polimerasi yang tinggi pada serat tersebut (Raden et al., 2016). Serat kapuk yang telah diekstraksi menghasilkan rendemen sebesar 32,99\% dengan berat 13,1960 gr. Proses preparasi bahan baku ini ditunjukkan pada gambar 2.

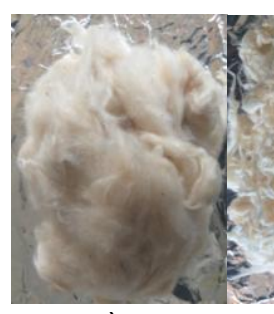

a)

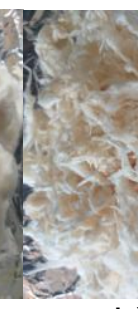

b)

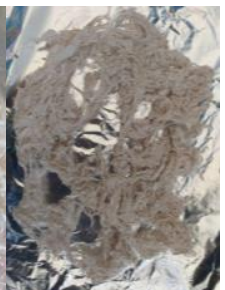

c)
Gambar 2. a) Kapuk mentah b) Kapuk setelah Bleaching c) Kapuk setelah Ekstraksi

\section{Sintesa Selulosa Asetat}

Pretreatment yang dilakukan sebelum pembuatan selulosa asetat adalah dengan perendaman selulosa kapuk yang telah diekstraksi dengan menggunakan asam asetat glasial dan asam sulfat selama satu jam. Perendaman ini bertujuan untuk merenggangkan ikatan kimia pada serat selulosa dan dapat memicu serat yang terasetilasi menjadi lebih banyak dan laju reaksi menjadi lebih cepat.

Reaksi asetilasi yang berlangsung adalah antara asetat anhidrida dan gugus hidroksil pada selulosa. Setiap subunit glukosa mengandung tiga gugus hidroksil dan hampir semuanya bisa untuk terasetilasi (Dow, 2012). Tipe reaksi ini biasa dikenal sebagai reaksi esterifikasi dan akan menghasilkan selulosa asetat yang larut di dalam pelarut asam (Analda Souhoka \& Latupeirissa, 2018). Kemudian reaksi dilanjutkan dengan penambahan air dan asam sulfat, kondisi ini akan menyebabkan terjadinya reaksi hidrolisa pada gugus asetil dalam selulosa triasetat dan mengkonversikannya kembali ke gugus hidroksil (Braun et al., 2013). Reaksi tersebut akan menghasilkan produk, yaitu selulosa diasetat seperti halnya yang dapat dilihat pada gambar 3 .

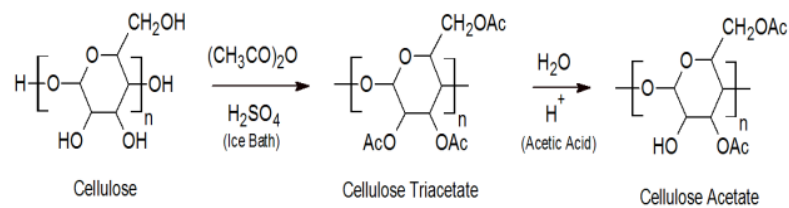

Gambar 3. Reaksi Pembentukan Selulosa Asetat (Dow, 2012)

\section{Pengaruh Waktu Reaksi terhadap Rendemen}

Kandungan selulosa yang telah diekstrak pada serat kapuk kemudian direaksikan dengan asetat anhidrida dengan katalis asam sulfat melalui proses asetilasi sehingga menghasilkan produk akhir berupa selulosa asetat.

Proses asetilasi yang terjadi terdiri dari dua tahapan reaksi, yaitu reaksi pembentukan selulosa triasetat dan hidrolisis gugus asetil pada selulosa triasetat kembali menjadi gugus hidroksil sehingga membentuk selulosa asetat (Rosnelly et al., 2010). Selulosa asetat yang dihasilkan dari penelitian ini akan terbentuk menjadi padatan berwarna putih dan terpisah dari air seperti terlihat pada gambar 4.

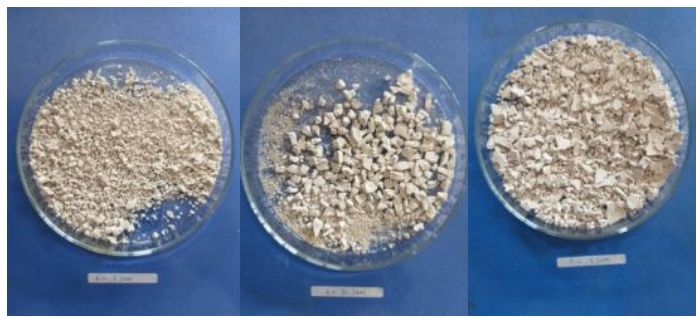
a)
b)
c)

Gambar 4. Selulosa Asetat a) $t=1$ jam; b) $t=2$ jam; c) $t=3$ jam 
Berdasarkan variasi waktu reaksi hidrolisis gugus asetil yang dilakukan selama 1, 2, dan 3 jam, didapatkan hasil rendemen selulosa asetat terbesar pada waktu reaksi hidrolisis 3 jam yaitu sebesar $138,264 \%$ dengan berat 6,913 gr. Data peningkatan massa selulosa asetat yang terbentuk terhadap lama waktu reaksi dapat dilihat pada tabel 3 berikut.

\begin{tabular}{cccc}
\multicolumn{4}{c}{ Tabel 3. Pengaruh Waktu Reaksi terhadap Rendemen } \\
\hline Sampel & $\begin{array}{c}\mathrm{t} \\
\text { (Jam) }\end{array}$ & $\begin{array}{c}\text { Berat } \\
\text { (gram) }\end{array}$ & $\begin{array}{c}\text { Persentase } \\
(\%)\end{array}$ \\
\hline 1 & 1 & 5,884 & 117,68 \\
2 & 2 & 6,789 & 135,778 \\
3 & 3 & 6,913 & 138,264 \\
\hline
\end{tabular}

Hasil tersebut menunjukkan bahwa terjadi peningkatan massa selulosa asetat yang terbentuk pada waktu reaksi yang lebih lama. Hal ini sama seperti yang dikemukakan oleh Syamsu \& Kuryani (2014), bahwa peningkatan waktu asetilasi menyebabkan selulosa memiliki waktu kontak yang lebih lama untuk bereaksi menjadi selulosa asetat pada rentang waktu 1 sampai 3 jam, namun apabila waktu reaksi melebihi 3 jam seperti yang dilakukan oleh Analda Souhoka \& Latupeirissa (2018), akan menyebabkan penurunan jumlah CA yang dihasilkan.

\section{Pencetakan Bioplastik}

CA yang dihasilkan kemudian digunakan sebagai bahan dasar pembuatan bioplastik selulosa asetat. Bioplastik dibuat dengan menambahkan gliserol sebagai plasticizer dan aseton sebagai pelarut untuk memudahkan proses homogenisasi campuran. Setelah campuran homogen, campuran kemudian dituang ke dalam cetakan dan dibiarkan hingga kering. Penampakan bioplastik yang dihasilkan dengan variasi penambahan jumlah gliserol seperti pada gambar 5 .

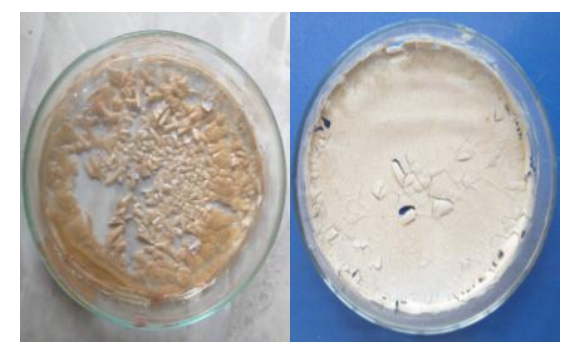

a)

b)

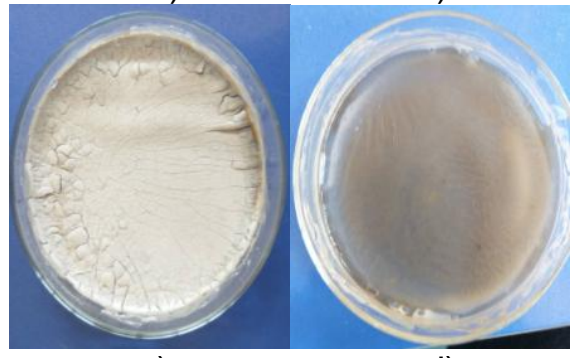

c)

d)

Gambar 5. Bioplastik dengan Tambahan Plasticizer a) nol; b) 20\%; c) $25 \%$; d) $30 \%$

Gambar 5 menunjukkan bahwa penambahan gliserol berpengaruh terhadap struktur dari bioplastik yang dihasilkan. Bioplastik yang dihasilkan tanpa penambahan gliserol cenderung mudah pecah dan rapuh. Seiring penambahan gliserol dapat terlihat terjadi perubahan fisik pada bioplastik yang dihasilkan. Bioplastik yang dihasilkan dengan tambahan gliserol $30 \%$ memiliki karakteristik fisik yang lebih halus dan tidak mudah retak bila dibandingkan penambahan gliserol $20 \%$ dan 25\%. Hasil tersebut didukung oleh Sjamsiah et al., (2017) pada penelitiannya yang menunjukkan dengan penambahan gliserol mempengaruhi sifat fisik dari film bioplastik. Penambahan gliserol akan berpengaruh pada tingkat fleksibilitas dari selulosa asetat. Jumlah gliserol yang lebih banyak akan meningkatkan fleksibilitas selulosa, sehingga dapat menghindari terjadinya plastik yang mudah pecah dan rapuh (Selpiana et al., 2015). Penambahan plasticizer gliserol juga dapat meningkatkan viskositas dan total padatan sehingga menyebabkan ketebalan film meningkat. Ketebalan film yang meningkat dapat menurunkan intensitas kecerahan film (Zubaidah, 2017). 


\section{KESIMPULAN}

Berdasarkan hasil penelitian dan pembahasan, maka dapat ditarik kesimpulan bahwa selulosa asetat (CA) dapat disintesis dari serat kapuk menggunakan asam asetat glasial, asam asetat anhidrida dan asam sulfat pekat. Jumlah rendemen selulosa terbanyak diperoleh pada waktu hidrolisis gugus asetil selama 3 jam dengan rendemen sebesar $138,264 \%$ dengan berat sebesar 6,913 gram, dan karakteristik fisik bioplastik yang lebih kuat dan tidak mudah rapuh terdapat pada sampel dengan penambahan gliserol sebesar $30 \%$ dari berat selulosa asetat.

\section{SARAN}

Penelitian lebih lanjut sebaiknya dilakukan terkait metode pencetakan yang digunakan serta perlu juga dilakukan analisa terkait sifat fisik dan kimia dari bioplastik yang dihasilkan. Selain itu, waktu reaksi yang lebih lama dapat dilakukan untuk mendapatkan titik optimum reaksi.

\section{UCAPAN TERIMA KASIH}

Penulis mengucapkan terima kasih kepada Jurusan Teknik Kimia Fakultas Teknik Universitas Sriwijaya sebagai fasilitasitator dalam penelitian ini. Tidak lupa juga kepada rekan sesama peneliti, analis laboratorium serta segenap pihak yang memberikan partisipasinya sehingga penelitian ini dapat diselesaikan dengan baik.

\section{DAFTAR PUSTAKA}

Analda Souhoka, F., \& Latupeirissa, J. (2018). Synthesis And Characterization Of Cellulose Acetate (CA) Sintesis dan Karakterisasi Selulosa Asetat (CA). J. Chem. Res.

Andaka, G. (2016). Sintesis Furfural Dari Kulit Buah Kapuk Randu Dengan Katalisator Asam Khlorida. Jurnal Teknologi Technoscientia, 9(1), 32-38.
Apriani, R., Rohman, T., \& Mustikasari, K. (2017). Sintesis dan Karakterisasi Membran Selulosa Asetat dari Tandan Kosong Kelapa Sawit (Synthesis and Characterization of Cellulose Acetate Membranes from Oil Palm Empty Fruit Bunches). Jurnal Riset Industri Hasil Hutan.

https://doi.org/10.24111/jrihh.v9i2.3305

Aripin, S., Saing, B., \& Kustiyah, E. (2017). Studi Pembuatan Bahan Alternatif Plastik Biodegradable Dari Pati Ubi Jalar Dengan Plasticizer Gliserol Dengan Metode Melt Intercalation. Jurnal Teknik Mesin. https://doi.org/10.22441/jtm.v6i2.1185

Asri, P., \& Tjahjani, S. (2015). Pemanfaatan Bungkil Biji Kapuk (Ceiba Pentandra) Sebagai Campuran briket Sekam. Padithe Utilization Of Cotton Seed Meal (Ceiba Pentandra) As A Mixture Ofa Rice Husk Briquette. UNESA Journal of Chemistry.

Astuti, H. O. T. (2005). Pengaruh Natrium Hidroksida dan Hidrogen Peroksida terhadap Rendemen dan Warna Pulp dari Serat Daun Nenas. Jurnal IImu Dan Teknologi Kayu Tropis, 3(1), 3743.

Braun, D., Cherdron, H., Rehahn, M., Ritter, H., \& Voit, B. (2013). Polymer Synthesis: Theory And Practice: Fundamentals, Methods, Experiments, Fifth Edition. In Polymer Synthesis: Theory and Practice: Fundamentals, Methods, Experiments, Fifth Edition. https://doi.org/10.1007/978-3-64228980-4

Carolina, A. (2010). Prarancangan Pabrik Selulosa Asetat Dari Selulosa Dan Asetat Anhidrid Dengan Proses Asetilasi Kapasitas 25.500 Ton Per Tahun. http://eprints.ums.ac.id/9078/

Dow. (2012). METHOCEL Cellulose Ethers Technical Handbook. Journal of the National Cancer Institute. https://doi.org/10.1093/jnci/djs080

Ellen MacArthur Foundation. (2016). The New Plastics Economy: Rethinking the future of plastics. Ellen MacArthur 
Foundation.

Elnashar, M. (2012). Biotechnology of Biopolymers. In Biotechnology of Biopolymers. ttps://doi.org/10.5772/683

Fajar, A. S., \& Hendrawati, T. Y. (2015). Proses Pengolahan Minyak Biji Kapuk (Ceiba Pentandra) Menjadi Methil Ester Melalui Proses Esterifikasi Katalis $\mathrm{KOH}$ Dan Waktu Reaksi. Teknik Kimia.

FAOSTAT. (2015). Kapok Fibre, Production Quantity (tons) - For All Countries. Factish.

Jambeck, J. R., Geyer, R., Wilcox, C., Siegler, T. R., Perryman, M., Andrady, A., Narayan, R., \& Law, K. L. (2015). Plastic Waste Inputs From Land Into The Ocean. Science. https://doi.org/10.1126/science.126035 2

Kathomdani, P. D. S. (2018). Pulp Kraft Dari Kapuk Dan Serat Daun Nanas Sebagai Bahan Baku Kertas Khusus. Jurnal Dinamika Penelitian Industri, 29(2), 108-118.

McKinsey. (2015). Stemming The Tide: Land-Based Strategies For A PlasticFree Ocean. 11-37.

Phisalaphong, M., Tran, T. K., Taokaew, S., Budiraharjo, R., Febriana, G. G., Nguyen, D. N., Chu-Ky, S., \& Dourado, F. (2016). Nata de coco Industry in Vietnam, Thailand, and Indonesia. In Bacterial Nanocellulose: From Biotechnology to Bio-Economy. https://doi.org/10.1016/B978-0-44463458-0.00014-7

Pratiwi, R. H. (2014). Potensi Kapuk Randu (Ceiba Pentandra Gaertn) Dalam Penyediaan Obat Herbal. WIDYA Kesehatan Dan Lingkungan.

Raden, Mardiyati; Reza, R., \& Steven, Arif; Basuki, S. (2016). Serat Kapuk Sebagai Bahan Baku Pembuatan Mikrokristalin Selulosa. Jurnal Sains Materi Indonesia.

Rohmawati, B., Sya'Idah, F. A. N., Rhismayanti, Alighiri, D., \& Eden, W. T. (2018). Synthesis Of Bioplastic-Based Renewable Cellulose Acetate From
Teak Wood (Tectona Grandis)

Biowaste Using Glycerol-Chitosan

Plasticizer. Oriental Journal of

Chemistry.

https://doi.org/10.13005/ojc/3404014

Rosnelly, C. M., Darwis, A. A., \& Noor, E. (2010). Pengaruh Rasio Anhidrida Asetat Dalam Proses Asetilasi Selulosa. Pulp Kayu Sengon (Paraserianthes Falcataria) Dalam Pembuatan Polimer Selulosa Tri Asetat. Journal of Agro-Based Indutry, 27(1), 1-11. http://ejournal.kemenperin.go.id/ihp/arti cle/download/2585/2019

Selpiana, Basri, T., \& Bakhtiar, N. H. (2015). Sintesa Bioplastik Komposit Limbah Ampas Tahu dan Ampas Tebu dengan Teknik Solution Casting. Seminar Nasional Teknik Kimia Indonesia V Dan Musyawarah Nasional Aptekindo.

Sjamsiah, S., Saokani, J., \& Lismawati, L. (2017). Karakteristik Edible Film dari Pati Kentang (Solanum Tuberosum L.) dengan Penambahan Gliserol. AlKimia. $\quad$ https://doi.org/10.24252/alkimia.v5i2.3932

Sugiyanto, S. A. S. T. (2013). Analisa Perilaku Mekanik Komposit Serat Kapuk Randu Menggunakan Matrik Polyester. Jurnal IImiah Teknik Mesin, $1(2), 65-72$.

Syamsu, K., \& Kuryani, T. (2014). Pembuatan Biofilm Selulosa Asetat dari Selulosa Mikrobial Nata De Cassava. Agroindustri Indonesia. https://doi.org/10.1007/s00227-0010737-x

Zubaidah, A. J. W. S. S. E. (2017). Pengaruh Jenis dan Konsentrasi Plasticizer terhadap Sifat Fisik Edible Film Kolang Kaling (Arenga pinnata). Jurnal Pangan Dan Agroindustri, 5(1), 13-25. 